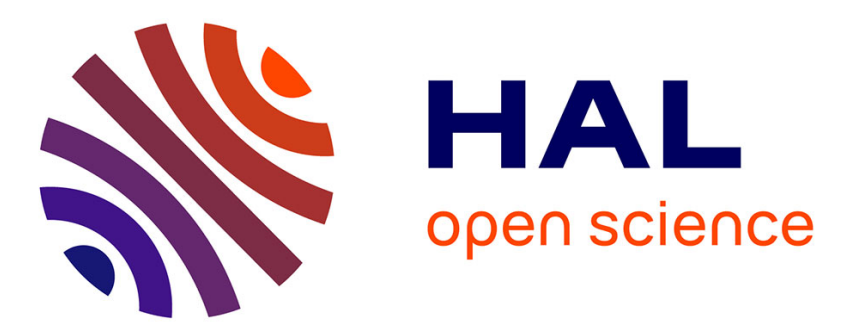

\title{
What does 'Culture' Mean in French? A Theoretical Mapping and Fractal Analysis of the Sociology of Culture in France.
}

\author{
Olivier Alexandre
}

\section{- To cite this version:}

Olivier Alexandre. What does 'Culture' Mean in French? A Theoretical Mapping and Fractal Analysis of the Sociology of Culture in France.. Cultural Sociology, 2018, 12 (4), pp.433 - 455. $10.1177 / 1749975518801656$. halshs- 01982760

\section{HAL Id: halshs-01982760 \\ https://shs.hal.science/halshs-01982760}

Submitted on 18 Mar 2019

HAL is a multi-disciplinary open access archive for the deposit and dissemination of scientific research documents, whether they are published or not. The documents may come from teaching and research institutions in France or abroad, or from public or private research centers.
L'archive ouverte pluridisciplinaire HAL, est destinée au dépôt et à la diffusion de documents scientifiques de niveau recherche, publiés ou non, émanant des établissements d'enseignement et de recherche français ou étrangers, des laboratoires publics ou privés. 


\title{
What does 'Culture' Mean in French? A Theoretical Mapping and Fractal Analysis of the Sociology of Culture in France
}

\section{Olivier Alexandre}

CNRS/LIP6, France

\begin{abstract}
This article charts the development of the sociology of culture in France. First, it examines the hypothesis of a French model, putting into perspective the correlation between cultural policies and dedicated sociological inquiries at the end of the 1950s. 'Culture' is one of the oldest fields of research in France, and current research still derives from the same anthropological matrix. Yet French sociologists present themselves as part of a divided and competitive academic domain. This article, based on an encompassing review of the literature as well as on in-depth interviews, accordingly distinguishes eight different 'schools' - organized around pre-eminent academics, concept producers and resource providers - as well as circles of collaboration. Whilst these circles organize their theoretical activity around emblems (with the word 'culture' referring to different conceptual sets) the social relations in their midst are organized around dyads, which usually transition from positive collaboration to rivalry. The article highlights the importance of these divisions as a fractal process and as boundary work for scientific production. From this perspective, the sociology of culture in France could be described as a large and extensive system of concepts and collaborations developed within small groups, within and between which, as with all 'cultural' matters, symbolic activity is the key basis for social status.
\end{abstract}

\section{Keywords}

Activity, arts, boundary work, dyad, emblem, fractal, France, intellectuals, Ministry of Culture, schools of thought, sociological tradition, sociology of culture

\section{Corresponding author:}

Olivier Alexandre, Campus Pierre et Marie Curie Sorbonne Université, LIP6, Boîte courrier 169, Couloir 25-26, Étage 3, Bureau 305, 4 place Jussieu, 75252 PARIS CEDEX 05, France. Email: olivier.alexandre@ehess.fr 
In a discussion with Pierre Bourdieu, Erving Goffman is reported to have referred to Distinction (Bourdieu, 1984) as 'a ground-breaking book about culture in France, and for the rest of the world, France means culture'. For French expatriates, this reverse exoti- cism manifests itself in many ways: painting, literature, cinema, architecture and music, but also wine, gastronomy, fashion, luxury and even the French accent are all regularly fetishized or labelled as 'culture'.

In seeming confirmation of this stereotype, the 'sociology of culture' in France has been one of the main sub-fields in the discipline throughout the last century (Alexandre, 2015). Nonetheless, numerous authors, from Emile Durkheim to scholars in postcolonial studies, have been accused in diverse quarters of weakening the French conception of 'culture': French sociologists who have worked on cultural phenomena have frequently been blamed for their alleged reductionism, materialism and relativism; however, this type of argument reproduces what it criticizes by reducing a heterogeneous set of works, with complex and sinuous histories, to a coherent and linear bloc. This performative contradiction comes with a degree of ambivalence: whereas French sociology of culture has been criticized as a factor causing cultural crisis, it has in fact become a symbol of France's cultural greatness. Examples include: the release of the complete works of Claude Lévi-Strauss in the prestigious 'Pléiade' Gallimard collection, dedicated to well- known writers; the influence of 'French post-structuralism' in the USA; and the way in which Pierre Bourdieu has remained the star (whether shining or dark) of French intel- lectual life.

From a strictly academic perspective, the frequency of references in North American peerreviewed journals to French cultural research provides a first indication of the international recognition enjoyed by the sub-discipline (Abbott and Ollion, 2016). Moreover, in addition to those French sociologists with a solid reputation abroad (Bourdieu, Passeron, Boltanski, Latour, Lahire), several sociologists trained in France who hold positions in foreign universities are playing an active role in research networks, and/or have relayed French research abroad. Conversely, France has welcomed sociologists from different parts of the world. Many well-known researchers have lived, worked and published in France since Karl Marx, including Norbert Elias, Howard Becker, Michèle Lamont, Yves Winkin and Marco Santoro. Also, France remains an attractive destination for foreign stu- dents particularly from Europe, Africa and Asia. Finally a significant number of articles and books offer state of the art accounts and overviews of the sociology of culture (Béra and Lamy, 2003; Coulangeon, 2005; Détrez, 2014; Dubois, 2016; Fleury, 2014; Moulin, 1994; Ravet, 2015).

At the same time, the institutionalization of the sub-discipline continues, opening up positions (one or two per year) for dedicated professors (Maffesoli, Menger, Fabiani, Péquignot, Pedler, Sapiro), thematic networks (art and culture - RT14 - of the French Sociological Association) and a dozen academic journals, half of them linked to major 
sociological figures (see Table A1 in the Appendix).

However, this institutionalization and international recognition of French sociology of culture has not produced a consensual definition or even a common denomination: 'sociology of culture', 'sociology of culture and education', 'sociology of art', 'sociology of the arts', 'sociology of arts and culture' circulate alongside more specific areas such as 'visual sociology', 'reception', 'literature', 'communication' and 'lifestyles'. None of these designations serves as a standard terminology. Furthermore, its scope also fluctuates, with research moving from a chiefly anthropological conception (culture vs. nature) to a more sociological meaning (the set of practices related to a specific group of people), validating or challenging long-standing normative classifications ('high cul- ture', 'cultivated culture', 'highbrow/lowbrow', 'dominated cultures') by contrast with other sub-fields such as rural sociology, the sociology of elites or the sociology of reli- gion, whose boundaries have remained more stable.

If I had to choose a metaphor to characterize this malleability, it would not be 'tricks' (Becker, 1986), 'imagery' (Shils, 1972), 'chaos' (Abbott, 2001) or 'catalogue' (Friedberg and Urfalino, 1984), but rather the 'chameleon' (Morin, 2006). In this regard, the only real limitation to the fluctuations and adaptability of French sociology of culture may be found in the controversies, arguments and clashes between different theoretical camps, with antagonized members pointing out irreconcilable differences rather than obvious similarities, such as linguistic and conceptual heritage and career paths. How can we explain the opposing properties of such a sub-field, on the one hand institutionalized, structured and internationally recognized, yet unstable, fragmented and divided on the other hand?

This article discusses the French model hypothesis, a common representation in France of the sociology of culture canvas as one moulded on cultural institutions and policies, rather than developing from an anthropological matrix, as previously assumed. Yet French sociologists present themselves as members of a divided and competitive 'turf'. In order to explain this paradox, I shed light on the fractal development of the sub- discipline. The gradual and continuous differentiation of ecologies of ideas, linked to ecologies of work, accounts for the fact that 'culture' as a concept has been used as an 'emblem' (Pastoureau, 1989), a sign of belonging to a social group on the academic scene. This understanding sheds light not so much on the meaning of the term, but rather on the French social organization of ideas and symbolic goods production, linking sym- bolic activity and social status.

\section{Methodology}

This study draws on five types of sources: archival work (at the History Committee of the Ministry of Culture) that determined what research projects had been supported by the 
Ministry of Culture from its creation in 1958 to 2013; an analysis of articles dealing with 'sociology' and 'culture' (reviews, interviews, obituaries) published in the daily newspaper Le Monde $(\mathrm{n}=47)$ as well as textbooks and scientific articles presenting a synthesis of the 'sociology of culture' $(\mathrm{n}=12)$; and, finally, a database compiled by the author, based on the national register of $\mathrm{PhD}$ theses, to establish the number of $\mathrm{PhD}$ dis- sertations defended in France between 1985 and 2017 that were related to culture $(n=357)$, excluding works claiming an affiliation with another sub-discipline or discipline, as well as dissertations not written in French. I read the summaries of the $\mathrm{PhD}$ theses thus identified, as well as the publications drawn from them which included 'soci- ology of culture' in their keywords $(\mathrm{n}=124)$.

On this basis, I conducted in-depth interviews $(n=34)$ with sociologists self-identify- ing as 'sociologists of culture' in their curriculum vitae, in their publications or through their involvement in two thematic networks: the RT14 'sociology art and culture' from the French Sociological Association (AFS) and the CR18 of the International Sociological Association in arts and culture (AISLF). The interviewee sample is based on three criteria (see Table A2 in the Appendix): status (all statuses were included: doctoral students, postdoctoral fellows, lecturers, CNRS-based researchers etc.) and importance in the field (publications, academic involvement, the number of theses supervised); representation of the various schools of thought; representation of all research centres in the 'sociology of culture' (Avignon, Besançon, Grenoble, Limoges, Lyon, Marseille, Metz, Poitiers, Paris, Strasbourg, Toulouse) without ignoring the Parisian demographic domination (more than two-thirds of $\mathrm{PhD}$ theses in the sub-field between 1985 and 2017 were defended in Paris). Finally, the article draws on participant-observation of six symposia and 24 thematic seminars, and on numerous informal discussions about the 'sociology of culture' in which I took part over the last decade. Given the demands of professional reputation in a 'small world' (Lodge, 1984), I limited the number of quotations and anonymized the interviewees included in this article.

From a theoretical point of view, one principle has guided my analysis of the material thus collected: to consider the 'sociology of culture' not as a profession (Piriou, 1999), a subspace (Bourdieu, 1990) or a case study (Fabiani, 2016), but rather as an activity (Abbott, 1988). In French sociology, this amounts to combining two research traditions: the sociology of intellectuals and the sociology of artistic work. Following the work of Bourdieu, the sociology of intellectuals became a dynamic area of research in France. It was originally premised on a parallel drawn between discursive and social positions (Bourdieu, 1990) within a space submitted to historical dynamics such as 'autonomization', 'internationalization', 'professionalization', 'feminization' and 'politicization'. Several ideal-types of intellectuals - 'organic', 'total', 'critical', 'prophetic', 'specific', 'collective', 'revolutionary' - were identified, framed by categories such as 'author', 'expertise', 'discourse' and 'responsibility'. However the legitimist bias of this tradition has been 
highlighted, especially with regard to the domains studied (philosophy, literature, fine arts) and to the choice of cases (the best and the most famous), with little consideration given to support personnel (Becker, 1982), ordinary workers and everyday experience.

Since the 1960s, however, the sociology of artistic work has developed a special interest in ordinary creators and their activities. As readers of Anselm Strauss, Eliot Freidson and Becker, several scholars have put 'work' at the centre of sociological in two ways. The first concerns market value, when 'work' is defined as an economic activity, focusing on remunerations and gratuities, volume and stratification, intermittency and regulatory systems. The second focuses on the socialization process (Lahire, 2006) and modes of sociability, both of street artists (Perrenoud, 2007) and of precarious artists (Alexandre, 2018), and the associated representations (Tasset, 2015).

This article is based on two simple ideas. The first is that French sociologists have a lot in common with artists, including: a highly asymmetrical audience for their work, semiprofessional control between trades and professions (Hughes, 1971) and continuous transformations of their production system. The second idea is to consider the 'sociology of culture' as an activity. This approach frees the analysis from symbolic stakes such as status hierarchy and label bias. I have therefore focused my research on the production activity of an object ('culture') related to social and intellectual trajectories, with each trajectory being an element of a relational system of people, organizations, concepts and ideas. The assumption is that this perspective will allow us to move beyond the distinction between 'good and poor' research while also shedding light on the divisions, conflicts and labelling that structure academic life (Lamont, 2009). In other words, by adhering to the symmetry principle (Bloor, 1991), I can neutralize the effects of symbolic boundaries (Lamont, 1992) while still placing them at the centre of the analysis. This approach invites a reconsideration of the French model hypothesis.

\section{The French Model Hypothesis}

The way 'culture' is defined in the French sociological tradition may be surprising from a British (Johnson, 1986), German (Moebius, 2008; Tenbruck, 1979) or North American (Alexander and Smith, 1998; Griswold, 2008) perspective. The 'cultural turn' never resonated, nor did it have any real equivalent, in the French history of the discipline (Rojek and Turner, 2000). This particularism may be related to the artistic tropism of the French sociology of culture. The role played by the arts in the rise of the bourgeoisie during the Middle Ages, the prominence of the arts at the king's court since the Renaissance, a legal system based on author rights since the time of Beaumarchais, Parisian centralism and the number of public organizations supporting 'culture' are the standard arguments defending the hypothesis of a 'French model' (Dubois, 2012). Based on an examination of the historical development of the sub- discipline, I advocate rebalancing this hypothesis. 
Indeed, research on 'culture' cannot always be assigned to political and administrative frames of reference (Muller, 2013). The image of an art-oriented sociology of culture took shape during the 1960s, when research on 'culture', opposing scientific work to ideological productions, spread from the same anthropological matrix. The Durkheim- Mauss-LéviStrauss lineage, based on strong ties (uncle, nephew then disciple) and institutional coherence (via the École Normale Supérieure and the Maison des Sciences de l'Homme), is today both shared and forgotten, with few researchers establishing a direct relationship between their work and these three classical figures.

Indeed, Durkheim (1912) made art an original case study for sociologists (Menger, 2014). Marcel Mauss pursued this orientation as the mentor of a small group of ethnologists at the Maison des Sciences de l'Homme during the interwar years, and as a theoretician of the gift and of body techniques. Lévi-Strauss, who was his student, became a world-renowned ethnographer of myths, personifying a paradigmatic revolution. In Paris, he had a lasting influence on a new generation of researchers which included Edgar Morin (1957), who studied stars as divinities; Roland Barthes (2006), who described fashion through its elementary structures; Gilbert Durand (1960), who depicted western imaginaries in the same way that Lévi-Strauss had analyzed myths; and Pierre Bourdieu, who used the tools of ethnography for analysing his own country, from the education system to museums and even his own birthplace. These important figures began their work during the 1950s and the 1960s, before establishing organiza- tions, through the Centre National de la Recherche Scientifique (CNRS, with Georges Friedman, Edgar Morin, Pierre Bourdieu, Raymonde Moulin, etc.), Ecole des Hautes Etudes en Sciences Sociales (EHESS), the universities (the Sorbonne, then Lille, Avignon, Vincennes, etc.) and scientific reviews, at the same time as the 'survey' emerged as the paradigmatic instrument and as a condition for academic validation (Masson, 2016).

Thus, even though I argue for a rebalancing of the 'French model hypothesis', the importance of the organizational sedimentation process should be stressed, guided as it was by political voluntarism, starting under the Popular Front, then continuing after the Second World War with several organizations such as the Filmology Institute (1946) and the Secretariat of Cultural Affairs (1959). More specifically, the programme administered by Augustin Girard as head of the Ministry of Culture Research Service, founded in 1963 (with a budget of 7 million francs in the 1970s) and known since 1986 as the Department of Studies and Research Foresight (Deps), helped to fund and maintain research partnerships (Martin, 2013). This school-of-thought-blind funding strategy of the Department resulted in numerous surveys on artistic institutions, consumption, training and employment (see Table 1).

Several academic journals associated with key figures in sociology placed culture at the centre of their editorial scope. These were Communication, founded by Roland Barthes and 
Edgar Morin in 1961, Actes de la Recherche en Sciences Sociales, launched by Pierre Bourdieu in 1975, Sociologie de l'art, established by Bruno Péquignot, André Ducret and Nathalie Heinich in 1992, and Culture et musées (1992), an important refer- ence in museology. New publications have recently been added to this list, thanks to junior researchers; they include Emulations in 2007, Poli in 2009, Reset in 2012 and Biens Symboliques/Symbolic Goods in 2017. Several peer-reviewed journals dedicated to media and communication research are also relevant because they regularly publish sociologists of culture: examples include Réseaux, Hermès, Questions de communication and Communication et languages.

This dynamism also shows on the educational front: there were only four academic courses on offer that were dedicated to culture in 1988; more than 200 were available in 2010, often including lectures in the sociology of culture. With regard to Masters and $\mathrm{PhD}$ courses, Parisian students beginning their studies after 2000 had a wide range of choices, both theoretically and socially, running from EHESS (Sabine Chalvon-Demersay, Fabiani, Heinich, Menger, Mauger, Dominique Pasquier and Sapiro) to Ecole des Mines (Antoine Hennion, Lucien Karpik), from Ecole Normale Supérieure (Frédérique Matonti) to Paris III (Péquignot, Eric Maigret), from Paris VII (Laurent Fleury) to Paris VIII (Henri Peretz, Rémy Ponton, Violaine Roussel), from Paris X (François Vatin, Gwenaële Rot) to Evry University (Jean-P. Durand, Joyce Sebag) and Sciences Po Paris (Philippe Coulangeon, Latour, Pierre François).

The density of work in these fields is compelling when compared with the parsimoni- ous treatment of artistic topics in other countries until recently: neither German nor Italian sociologists have any thematic journal in the sociology of arts or culture, and only $0.5 \%$ of the Italian publications in sociology dealt with artistic topics during the late 1990s (Heinich, 2001). Finally, whilst North American cultural sociology has been beset by deep divides about its principles (Krause, 2016) to the point of 'incoherence' (Smith, 2016), cultural sociology in France could be defined as socially and intellectually coherent, with Bourdieusian sociology as its theoretical and social gravitational centre (Paradeise et al., 2015: 77-82; Schnapper, 2013). 
Alexandre 439 Table 1. Social science 'laboratories' and researchers funded by the Deps (1962-2013).

Sociologists (topics, publication year of funded research)

Crozier (television, 1966); Friedberg, Urfalino (artistic administrative decentralization, 1984); François (art music, 2008) Hennion (music industry, 1978); Hennion, Gomart, Maisonneuve (amateur musicians, 2000)

Bourdieu (museums, 1966); Sapiro (translation, 2012); Dorin (music, 2013) Moulin (architects, 1973; fine arts, 1977); Menger (art music, 1989; television and cinema employment, 1996; professional comedians, 1997); Coulangeon (professional musicians, 2004); Rannou, Roharik (professional dancers, 2006)

Ethis (Cannes festival, 2001; Avignon festival, 2002) Berthomier, Detrez, Merckle, Octobre (children and teenagers' cultural practices, 2010) Lizé, Naudier, Roueff (artistic intermediaries, 2011) Durand, Sebag (graphic design, 2011) Beuscart, Mellet (professional advertisers and advertising market, 2012) Glevarec (cultural patrimony, 2002; cultural consumption, 2009)

Guibert (contemporary music, 2012) Bajard, Doga, Perrenoud (artwork, 2011), Ancel (exhibitions, 2014) Sirota (children's cultural practices, 2013) Chaumier (museums, 2013)

Source: Deps.

However, this seeming homogeneity needs to be viewed in a more nuanced way. Despite their visibility, the arts represent only $30 \%$ of the central themes of $\mathrm{PhDs}$ related to the sociology of culture that were defended between 1985 and 2017. Therefore, the arts represent an important theme, but not to the exclusion of others. Topics commonly associated with 'culture' include education, sport, lifestyle, professional groups (from firefighters to computer engineers), gender, race, and the life course (childhood, youth, ageing), media and representations, modes of sociability and everyday practices. Moreover, 'France' as a whole is the scale of reference for just a few surveys, especially $L$ 'Esprit $d u$ temps (Morin, 1962), Distinction (Bourdieu, 1984) and Pratiques culturelles des français (Donnat, 2009). Most of the research focuses on street-level organizations (one or groups of libraries, museums or schools), a neighborhood, a city or one part of the country, usually based on the administrative unit (departments and regions). Furthermore, foreign territories or countries frequently serve as points of comparison or as objects of analysis as such: the favelas of Rio, the entertainment industry in Athens, gastronomy in Lima, as well as various subjects relating to African countries, partly because of France's colonial past and partly due to ongoing research connections. The geographical coherence of the sociology of culture as 'made in France' therefore remains relative. Moreover, numerous researchers affiliated with it feel part of a conflicted and competitive 'turf', or territory (Abbott, 1988), 
despite the common institutional frame- work underlying their activities and career paths (Lisbon agreement, PhD defences, Conseil National des Universités - CNU - certification, Agence d'évaluation de la recherché et de l'enseignement supérieur - AERES - etc.).

In the interviews, the term 'schools' is regularly used to distinguish the various competing groups, and it is noteworthy that 'school' has both a theoretical and military sense: loyalty among members is based on a community of values and interests in competitive opposition to other groups. In its strongest and most stable sense, the notion of 'school' defines a relatively independent and homogeneous group, both socially and theoretically, based on common activities, developed around a central figure as producer of concepts and resource manager. This 'great man' (Godelier, 1986), an ironical but correct depiction since, indeed, female figures here have been very rare (Raymonde Moulin excepted), usu- ally leads circles of collaboration through workshops, editorial activities (scientific jour- nals and book collections) and by controlling chains of opportunity (scholarships, funds, participation in selection committees). 'Schools' tend to be designated through the last name of their 'great man', positively or negatively according to the moment and the speaker ('he or she is a Bourdieusian', 'a Boltanskian', 'a Latourian', 'a Mengerian', etc.). The different meanings of the word 'culture' can help to chart the sub-discipline.

\section{Culture Mapping through 'Schools'}

On the basis of my review of books and textbooks, as well as my analysis of the inter- views and observations carried out, I distinguish eight ways of encoding 'culture', related to as many 'schools'. The group identified with Pierre Bourdieu is the most frequently mentioned. The sociologist is presented as a consensual hyphen ('we are all Bourdieusians' a French doctoral student on the University of Chicago campus once told me) or, conversely, as a figure to oppose. Often described as coherent and systematic, the 'sociology of Pierre Bourdieu' was nevertheless shaped through different disciplines (anthropology, history, philosophy), theoretical influences (Ernst Cassirer, Erwin Panofsky, Erving Goffman, Harold Garfinkel, etc.) and through collaborations (at the Centre de Sociologie Européenne with Yvette Delsault, Marie-Christine Rivière, Monique de Saint-Martin, Rémi Lenoir, Boltanski, etc.). Indeed Bourdieu's ambition to develop a 'critical sociology' stemmed from his determination to transcend the limiting analytical scope of Marxism and Existentialism, anthropology and economics by studying the symbolic dimension of transactions and interactions. This analytical openness paradoxically operates through an extension of the economic repertoire ('capital', 'profitability', 'utility', 'investment', etc.) to practices traditionally considered as infrarational (social institutions). The decision-making instance is then transposed from the individual unit of economics to a collective entity - 'society' - itself decomposed into differentiated 'social spaces' designated and analysed via the physics metaphor of the (magnetic) 'field'. Within it, the position of 'agents' is both a function of, and at the same 
time determines, their 'lifestyles', defined as systems of tastes and interests. From that perspective, the social clock obeys a praxeological mechanism - or, in other words, agents are classified by their rankings.

Whilst Pierre Bourdieu did not publish any work specifically dedicated to 'field theory', Rules of Art (1996) comes closest to providing a comprehensive statement. Extending the sociology of creators developed in the 1970s to an analysis of the French literary field in the 19th century, the book is built on a chiasm and symmetry between the heteronomous pole of commercial production and the pole of works with a longer-term, slower diffusion process. This model provides the theoretical framework of the best- structured school of French sociology, in which culture is an emblematic topic. Only five of the 43 theses supervised by Bourdieu are directly related to the artistic field (Henri Peretz on art criticism in 1972, Rémy Ponton on literature in 1977, Heinich on painting in 1980 and Sapiro and Pascale Casanova on literature respectively in 1994 and 1997); however, most of them inquire into 'cultural' issues. Many of Bourdieu's former students and close collaborators are associated today with the sociology of culture sub-field. From this perspective, it is possible to distinguish those who have distanced themselves, theo- retically and socially (Passeron, Jean-Claude Chamboredon, Yvette Delsaut, Boltanski, Fabiani, Heinich), from those who have remained faithful to him (Mauger, Louis Pinto, Patrick Champagne, Sapiro, Julien Duval). Yet the death of the 'boss' led to an opposition between the 'historical' representatives (Mauger, Pinto, Lenoir, Champagne) and a new generation (Franck Poupeau, Sapiro, Matonti, Duval) competing over his institu- tional as well as his theoretical legacy. In the meantime, several sociologists particularly active in the discipline (Boltanski, Fabiani, Heinich, Lahire, Eric Maigret, Jean-Marc Leveratto, Jean-Pierre Esquenazi) continue to define the specificity of their approach through their differences from the Bourdieusian model.

Becker has been extensively mobilized since the end of the 1980s as a theoretical alternative to Bourdieu's approach. This function - ironic for a Californian and Midwest style sociologist - partly explains the consensual position of Becker for and between groups that view themselves as dissimilar. Art Worlds was translated by Menger in 1988, and Becker was a visiting scholar at the Centre de Sociologie du Travail et des Arts at the invitation of Raymonde Moulin in 1989, and a visiting researcher at the Centre de Sociologie de l'Innovation during the second half of the 1990s. He was honored by Alain Pessin in a dedicated book (Pessin, 2004), and was regularly invited by Péquignot to his seminars since 2000; he collaborated with sociologists as different as Marie Buscatto, Jean Péneff and Daniel Cefaï, and is commonly cited by sociologists identified with Bourdieu. Becker has also been living in Paris for three months each year since the end of the 1990s. The pedagogical tone of his publications as well as the seductive character of his topics for student audiences (cannabis use, ordinary musicians) may explain how this American sociologist, readily referred to as 'French' in the USA (Gopnik, 2015), is deemed a classic 
in France. This recognition is even more surprising consider- ing the genealogy of his intellectual trajectory: before having a profound influence on French sociology, Becker had been a self-taught and attentive reader of the French 'sociology of culture', and was especially acquainted with the work of Bourdieu and Raymonde Moulin.

The first monograph by Raymonde Moulin, The French Art Market (1987), originally published in 1967, solves the apparently insoluble question of the value of pictorial works and its relation to their economic conditions of production as well as to the market organization of art supply and demand. The author is directly connected to the sociological tradition of institutions and economic analysis through Raymond Aron, her doctoral supervisor. She describes the classifications ('conservative' and 'movement', 'classical' and 'consecrated' works), beliefs ('love', 'singularity', 'sacred') and local organization (galleries, museums, Paris and regional markets) of an extensive network of painters, brokers, curators, gallery owners, art critics, collectors and amateurs, unravelling the various manifestations of the hiatus of the price valuation of 'things without price'. For 50 years, Raymonde Moulin was one of the few female figures central to the discipline in France (CNRS, EHESS, and she was the founder and director of the Centre de sociolo- gie des arts, as well as the director of the Revue Française de Sociologie). She has mentored numerous sociologists, starting with Menger, her former $\mathrm{PhD}$ student who replaced her both as director of the Cesta (Centre de sociologie du travail et des arts, successor to the Centre de sociologie des arts) and as director of the Revue Française de Sociologie. In the 1980s, Menger initiated an ambitious research programme, shifting the question of value inequality from works to artists. Becsause he is a careful reader of the North American economy and sociology of work (Hughes, Stinchcombe and Becker, who used Moulin's work to write Art Worlds, before he was in turn referenced by Menger), he defines art markets and creative activities through an analytical focus on processes, paying close attention to the temporal springs of 'action', 'apparatus', 'projects' and 'careers'. He refers to the cumulative logics of the Matthew effect in order to solve the Paretian enigma of compensation and the asymmetric distribution of reputation. In a parallel endeavour, Pasquier, also a former PhD student of Raymonde Moulin, developed a sociology of work in the media in collaboration with Sabine Chalvon-Demersay, pay- ing attention to production, representation and reception processes (Pasquier, 1999, 2005). Moulin and Menger's other students have addressed a similar problematic, for example in contemporary art (Alain Quemin), in architecture (Florent Champy), for jazz musicians (Philippe Coulangeon), in art music (Pierre François) and in leisure activities (Sylvie Octobre and Hervé Glevarec).

Distancing himself from the normative and empirical limits of the Bourdieusian model in Le Savant et le populaire (Grignon and Passeron, 1989), Passeron, who previously collaborated with Bourdieu, proposed an empirical alternative to the legitimist apprehension of culture. In keeping with the intellectual legacy of Richard Hoggart and the 
School of Constance, he gathered a group of sociologists including Chamboredon, Jacques Cheyronnaud, Fabiani, Emmanuel Pedler and a few historians such as Paul Veyne, at EHESS Marseille and the Sociologie, histoire, anthropologie des dynamiques culturelles centre (Shadyc). This 'Marseille moment' of the French sociology of culture, grounded in a historical and transdisciplinary epistemology (Passeron, 2005), extended through the 1990s. It is distinguished by close attention to local communities of recep- tion, and to the modes of perception of artworks without ignoring processes of social domination. As a result the vertical dimension of Bourdieusian sociology is approached in a more temporal mode. In practical terms, this epistemological move consists of put- ting into perspective the structuralist indicators of economic, social and cultural capital by focusing on space and time variables, following the programmatic survey developed by Passeron and Pedler to contrast levels of engagement with paintings in museums (Passeron and Pedler, 1991). This reappraisal of the significance of temporality and tem- poral processes over and above structural aspects can be seen in a whole array of studies (Djakouane, 2011; Malinas, 2008), many of which explore the reasons for low cultural participation or that examine the specificity of reception in Provence, for example at the Granet Museum in Aix-en-Provence (Passeron and Pedler, 1991), in libraries in the PACA region (Pedler and Zerbib, 2001), at the Cannes Film Festival (Ethis, 2001), at the Avignon Theatre Festival (Ethis, 2002) and in the Marseille music scene (Pecqueux and Roueff, 2009). The prevalence of the temporal can also be seen in the choice of the arts studied - with a preference for temporal arts such as music, theatre and cinema.

In attempting to synthesize the contrasting perspectives of Bourdieu and Passeron, the work of Lahire (2004) marks an important inflection point. Basing his theory on a close reading of Bourdieu's work, Lahire points out key limitations of the concepts of 'field' (which Bourdieu universalized from a local and historical configuration, essentially 19th-century Paris) and 'habitus' (which lacks specificity as far as mechanisms of social impregnation are concerned). Based at the Ecole Normale Superieure de Lyon, Lahire has sought since the end of the 1990s to shed light on how individual psychology bears the traces of successive social experiences through different social institutions: family, school, friends, hobbies, politics, media and so on. By placing greater importance on complex socialization paths than the author of Distinction did, Lahire presents a more flexible model, related to a society considered more adaptive, complex and flexible due to the urbanization process, the growth of unemployment, the lengthening of the lifespan, the democratization of education, the expansion of cultural industries and the media, and electoral volatility. Books such as The Plural Actor (Lahire, 2010) highlight the role of social 'dispositions' for each individual, rather than stable and unique social positions within a field. His work has benefited from teamwork with Pierre Merklé, Muriel Darmon, Christine Détrez, Lillian Matthieu and numerous $\mathrm{PhD}$ students (often working on literature and art).

French pragmatism is for its part not in critical dialogue with Bourdieu's theory, but has 
instead engaged in systematic and wholesale antagonism, in particular by revisiting the issue of social organization on the basis of the significance of action, values and meanings. French pragmatism, whose engagement with the methodological heritage of William James, John Dewey and George Herbert Mead is somewhat loose, developed in the second half of the 1980s in Bruno Latour's seminar at the Centre de Sociologie de l'Innovation of Mines School and at the Groupe de Sociologie Politique et Morale led by Boltanski and Laurent Thévenot at EHESS. Actors' speech constitutes the touchstone of On Justification (Boltanski and Thévenot, 2006) and thus underpins a shift from critical sociology to the sociology of criticism, and thus from the social to the linguistic and semiotic. Linguistic acts or discursive continuities are deduced from socially structured and stabilized systems of values (the 'cities'), which are no longer seen from an overhanging position as anchor points on the scale of social stratification, but are instead returned to a flat perspective. A similar approach can be identified in work on artistic critique, as a historical process reforming capitalism (Boltanski and Chiapello, 2005 [1999]) and, for example, in Heinich's analyses of how artists, gatekeepers and audiences are gathering and fighting through ritualized scandal sequences on the contemporary art scene (Heinich, 1998). More distanced from the linguistic turn, Antoine Hennion (1993) and Jean-Marc Leveratto (2000) brought the analysis of cultural tastes back to the forefront of the social stage. The 'hinterworld' of social determinations gives way to the conditions and modalities of aesthetic pleasure. Actor-network theory supports the microstudy of mediations and incorporates techniques in the study of amateurs of Baroque music, Italian comedies and wine-tasting.

Also readers of Latour, the members of the following group place media at the heart of social and historical dynamics. Whilst some of them claim the influence of Edgar Morin and Alain Touraine, intellectually they are more indebted to Anglo-Saxon theories, to which they were exposed during academic visits to the UK and the USA. The intellectual epicentre of this French reinvestment of the media has been EHESS Paris, through two seminars organized in the 1990s and 2000s respectively by Dominique Mehl ('Media and Manners'), then by Eric Macé and Eric Maigret ('Cultural Studies'). Reinvesting in the Columbia, Chicago and Birmingham Schools, and restoring Edgar Morin's intellectual legitimacy, this school of thought focuses on mass media (television, newspapers, comics) and pop representations (superheroes, anchormen) to cast light on relations of power (Macé and Maigret, 2005). The media space is described as a conflicted arena, open to subversive strategies from social and political minorities (Quemener, 2014). The delimitation between cultural legitimacy and illegitimacy is thus reversible, based on the numeric criterion of minority and majority and its declension at the three stages of the pragmatic sequence of work (codes), diffusion (encoding) and reception (decoding), in studies of boundary objects such as pornography (Vörös, 2015) and geek culture (Peyron, 2013). This perspective tends to blur the boundaries between art and culture, creation and reception, with the sociology of culture à la française rising up from its cognitive and institutional foundations to join a 
larger and more international current, putting identity logics and boundaries into perspective (Cervulle, 2013).

Maintaining a social proximity to the previous group through symposiums, publications, collaborations and friendships, the seventh academic stream also interrogates the meanings of art works, whilst the different traditions described earlier presented the common feature of being subjectively motivated by taste for the arts while confining the analysis of art works to a blind spot. For that reason, the formalist approach has long remained the black hole of the French sociology of culture. Thanks to the opening of departments in Grenoble, Besançon, Metz and then Paris III, the sociology of art works was developed on the basis of social history, psychoanalytical tools and philosophical background, summed up in the expression 'French theory' (Louis Althusser, Gilles Deleuze, Jacques Derrida and Michel Foucault). In this tradition, works and representations are decomposed into points of semantic socially signifying coordinates (as Lévi-Strauss did with myths). Selected on the basis of the personal taste of the researcher and the popularity of the object, romantic novels (Péquignot, 1991), the modernity of cinema (Esquenazi, 2004), contemporary art (Sauvageot, 2007) and TV series (Esquenazi, 2010) are considered in the same way as Las Meninas was by Foucault, with the aesthetic structure of the work being related to the historical struc- ture of society (Péquignot, 2000).

Finally, the eighth stream revolves around the personality of Michel Maffesoli. A founding member of the 'Grenoble School', of which Pierre Le Quéau is the last representative, Maffesoli leads a large network of researchers and $\mathrm{PhD}$ students, half of them foreigners (mainly from Brazil, Italy and South Korea). A sociologist, he has been influenced profoundly by anthropology and specifically by the works of Jean Duvignaud, Georges Balandier and Gilbert Durand (his doctoral supervisor). He represents 'postmodernism', yet references classical concepts such as 'tribes', 'nomadism' and 'vitalism'. Crossing over disciplinary boundaries, he enquires into social imaginaries, rearticulating the relationship between individuals and society through images and representations. His prolific postgraduate supervision at Paris V (more than 140 supervised theses, placing him far ahead of other supervisors in French sociology), his media pres- ence and his role as academic manager (hosting meals, dinners, parties and so on) go hand in hand with relatively autonomous working conditions, a long career in the same department at Paris V, his own laboratory (Centre d'Etudes sur l'Actuel et le Quotidien) and his own scientific journals (Sociétés and Les Cahiers européens de l'Imaginaire). Caught in a series of polemics, he has been marginalized from the discipline, and his students and publications have also been affected. However, some of his $\mathrm{PhD}$ students have become established in the academic system, both in France and abroad.

\section{Fractal Development}


This description, based on 'school' identification, is not a pure reference to the mandarin system (Mendras, 1995) or to the sociological Yalta and the 'gang of four' (Bourdieu, Crozier, Touraine, Boudon). First, 'schools of thought' should be distinguished from 'schools of activity' (Gilmore, 1988). Second, 'school' is a strong word for designating different types of groups, from funded official academic organizations to small and informal circles of collaboration (Farrell, 2001). Finally, these groups are characterized by different life-spans, from a couple of years to several decades. It is thus remarkable that the previous mapping, though seemingly exhaustive, does not include all the works in the subdiscipline. Indeed some of these have been coined by many a doctoral student or researcher preparing or holding a $\mathrm{PhD}$ identified with other thematic networks (with supervisors such as Raymond Boudon, Alain Touraine, Alain Gras, Dominique Desjeux, François Dubet or Renaud Sainsaulieu), with other disciplines (political science, communication studies, management, education sciences, performing arts and history) or pursuing a career in a different country. Nonetheless, interviewees described themselves as part of a competitive 'turf' (Abbott, 1988), with allies, rivals, enemies or sometimes complete strangers. Like many intellectual activities, this way of describing the organization of a profession may appropriately be analysed according to a fractal principle. Andrew Abbott emphasizes two differentiation processes in scientific activity - one social (Abbott, 1999) and the other theoretical (Abbott 2001) - but it is possible to link them, with the first one activating the other and vice versa.

Indeed, each researcher and their work is located in a large network of references and affiliations in time and space. This objective interdependence comes with a continuous series of subjective distinctions, transforming academic rites and certifications (defences, publications, reviews, proposals) into a labelling activity. Thus a dynamic of scissiparity emerges, fuelled by accumulation and complementarity effects, rivalries of age and career paths, structuring the genealogical tree of French sociology of culture. Each author is positioned in a system of ramifications, localized and partially described during the interviews. Researchers do not feel that they are part of the net- work as a whole, and tend to focus instead on their own collaborative circle and direct rivals.

In order to build a better picture of this way of representing themselves, it is fruitful to take into account the successive social and theoretical sequences of the interviewees' career paths, connecting different collaborative groups and different networks of concepts. The uncertainty of the scientific trajectory and the anomie that is characteristically experienced during the $\mathrm{PhD}$ process (due to the lack of scientific references, theoretical frames, supervision and so on) tend to lead to the formation of more or less sustainable horizontal, homosocial and collaborative dyads. 'Culture' is the primary area of research investigated by each of these dyads, with each of the two members factoring in the comparative advantage of the other (qualitative/quantitative, theory/ empirical, survey/writing, sociological expertise/related disciplines). Furthermore each dyad is based on the elective 
affinity and moral complementarity of its two members with regard to possible alternative pairings. The same logic could be highlighted for more established dyads (which sometimes widen to encompass a third member): for example for Bourdieu-Passeron, FabianiMenger, Chalvon-Demersay-Pasquier, Macé-Maigret, Leveratto-Montebello, De Verdalle-Rot, Détrez-Octobre, Péqueux-Roueff, Moeschler-Thevenin, Ethis-Malinas, Lizé-Sofio, Pilmis-Cardon, Noel-Pinto, Jordan-Naulin, Eloy-Legon and others.

During the $\mathrm{PhD}$ period, these collaborations involve complementary activities: readings, surveys, theoretical work, argumentation, scientific responsibilities, research administration, fundraising, editorial activity and so on. From a theoretical viewpoint, the challenge for the dyad is to broaden and deepen its repertoire in order to show expertise (through the 'state of the art' section of the thesis), and at the same time approach an 'author's aura' (Foucault, 1972). This double bind is often solved through the exclusive, but also successive, identification with one model, even though the $\mathrm{PhD}$ sequence is in fact often an experimental and random initiation to different theoretical and methodological orientations.

The 'bricolage' metaphor (Lévi-Strauss, 1966) comes to mind, provided bricolage is understood in the sense of artisan craft. Researchers seek to craft and shape a presentable object to themselves and their peers, not a perfect object (Becker, 1986). Like jazz musicians, sociologists collect and combine pre-existing pieces to produce acceptable performances for their audience (Becker and Faulkner, 2009). These sources and resources are mingled, usually with little regard for the boundaries between 'schools' or circles of collaboration (Abbott, 2001). The notion of 'poaching' (Abbott, 1988) is suitable for describing this sort of intellectual work. Many sociologists describe their $\mathrm{PhD}$ cursus along these lines: 'back then, I was trying like hell to sort all this out', 'a lot was passing me by at that time', and so on. Taking these modalities of scientific production into account leads to acknowledging the importance of borrowing and incremental synthesis, even though such processes may be unconscious and perhaps even amount to a strategic faux-pas. This is reminiscent of Harold Garfinkel's advice to some students to "continue to "misread" Husserl, Heidegger and Merleau-Ponty like [he] did, by bringing them to their own fields and questions' (Lynch, 1997: 117). From this perspective, the concepts that qualify 'culture' act as boundary objects (Star and Griesemer, 1989), sometimes serving to articulate elements and pieces borrowed from different social spaces and times, but also mobilized to distinguish competing people or groups from one another. This practice explains why different authors who see themselves as theoretically irreconcilable are regularly found side by side in $\mathrm{PhD}$ thesis chapters.

These 'unnatural' associations find a stabilized form with negative dyads - the counterparts of collaborative ones. These commonly result from collaborations that have soured, but they are also the culmination of long-term rivalries due to age proximity (as this implies 
cumulative competition for funding, positions, recognition, etc.). Differences that could appear minor are then dramatized and aligned with theoretical stances drifting apart. Such a characterization may apply for example to the dyads Bourdieu-Passeron, BourdieuMoulin, Bourdieu-Boltanski, Fabiani-Pinto, Menger-Heinich, Lemieux-Maigret, Malinas-Djakouane. Bourdieu simultaneously embodied and transformed these conflictual relationships into an action system, not only between concepts (subjectivism/ objectivism, theory/practice, etc.), but also between people, both outside and within his school of activities. Regularly highlighting what distinguished him from his colleagues/com- petitors, he also encouraged what could be called 'everyday confrontations of habitus' amongst researchers, through direct collaborations or outright competition on the same topic.

From a fractal perspective (Abbott, 2001), scholars' desire to make a 'difference' or initiate a theoretical bifurcation is seen as typically originating in social rivalries, antagonisms or bitterness within schools of thought, schools of activities or informal collaborative circles. For example, the short and strictly intellectual collaboration between Passeron and a political figure close to the 'second left' in the late 1960s weakened the Bourdieu-Passeron dyad, leading to a 30 -year theoretical, professional and social rivalry. The story goes that for 20 years Passeron avoided Bourdieu on the Boulevard Raspail pavement where EHESS is located (both were members of the institution). The book Le Savant et le populaire (Grignon and Passeron, 1989), a major contribution to French sociology of culture, could be read as an in-depth inventory of Bourdieu's thought. The latter's silence about it was broken with a bitter and ironic literary wink, in the French tradition of verbal battles, with La misère du monde (The Weight of the World) (Bourdieu, 1999). Still one of Bourdieu's greatest literary successes, the book's title was an implicit and provocative echo of Grignon and Passeron's analysis, and the moral symmetry they drew between legitimism/miserabilism and popular/populism.

This mode of development in the sub-discipline has had numerous other, less publicized, occurrences. There are two reasons to focus on these moments. First, they capture how and why theoretical proposals emerge and are presented as radical alternative solutions to common and consensual problems. The same core problems are progressively diffracted by scissiparity, with researchers highlighting marginal differences that are nevertheless objectively differentiating on the common 'turf', just as French Marxist theorists in the 1950s and 1960s went through numerous clashes and divisions despite their common line (Abbott, 2001: 24). These diffractions usually come with 'genesis amnesia' on two levels. First, a form of secrecy recovers this dialectic of resentment, leading to social and theoretical rivalry. Humiliation, jealousy, anger and resentment are all long-lasting emotional factors in academic distinction. Secondly accounts of differences tend to focus on their scientific dimension and to characterize them as ruptures leading to innovation, which also means marginalizing any acknowledgement of proximity and continuity: 
I do think that there is an active cumulativeness principle in what we do. That Pierre Bourdieu with Distinction reaches the highest level revealing a certain truth, in relation to this way of tackling the question; and that, this doesn't need to be done again. But when I say that to my pragmatist friends, they tell me: gosh, are you mad?! How can you say such a thing? For them, it's just wrong, and we've done something brand new and innovative; so I keep it to myself ...

(Interview with a (senior) sociologist self-labelling as 'pragmatist', 2014)

Recurrent distinctions between branches of the same family of problems and groups of researchers tend to feed the oppositions within the same group, or exacerbate those that separate two groups - especially when they are characterized by the closest analogies: 'old' Bourdieusians against 'young' Bourdieusians; 'Bourdieusians' against 'Lahirians'; 'Boltanskians' against 'pragmatists'; 'Beckerians' against 'Latourians' and so on. Positive ways of establishing these theoretical differences include: enlarging the scope of theoretical possibilities by borrowing from other disciplines (anthropology and philosophy for Bourdieu; linguistics and epistemology for Passeron; philosophy and economics for Menger; history and psychology for Lahire); or from sociology in other countries (Passeron as translator of Hoggart; Menger as translator of Becker; Maigret as translator of Jenkins; Cervulle as translator of Butler). Another strategy for expanding resources on which to draw theoretically is requalifier (to rehabilitate) a thought that previously had been determined obsolete, such as that of Edgar Morin. His thesis about 'culture' initially was successful, both within academia and beyond, in the 1950s. Then it was partly déqualifié (critiqued) by Bourdieu-Passeron within the French sociological community during the 1960s (Bourdieu and Passeron, 1963). Finally, in the 2000s, Macé and Maigret (2005) attempted to requalifier (reintroduce) his thought. This recognition cycle has inspired these (informal) words from Morin: 'their academic qualification has been my requalification'. Many authors have met a similar fate, passing from academic, and sometimes media, acclaim to obscurity; for example, Lucien Goldmann, Jean Duvignaud, Pierre Francastel, Joffre Dumazedier and many Marxist authors are rarely read today despite their large influence in the 1960s. In contrast, Stuart Hall and Norbert Elias are now reaching an important audience in France. Thus it might be theoretically fruitful to combine fractal analysis with the analysis of theoretical production.

\section{Culture as Emblem}

This analysis need not be restricted to the French sociology of culture, and the same observations could be made about other scientific or creative fields. Yet they have a particular relevance here. Indeed, defining 'culture' through differentiated repertoires is an invitation to read the history of the sociological tradition on two levels: one relating to scientific productions; the other associated with boundary work, following a common 
relational perspective (Mannheim, 1954). Analysing conceptual production as an activity subjected to cumulative shifts, social evaluations and evolutions of meaning can be taken as a plea for a better understanding of the hiatus between the ecology of concepts, opened to influences and adaptation throughout their careers, and the ecology of work in small circles of collaboration, localized socially and historically. From that perspective, each proposition is presented as new, disruptive or simply differentiated in relation to sociology as an indivisible and coherent whole. Readers, commentators, producers and evaluators in the field use concepts in the manner of boundary objects, mobilizing them, diverting them, routinizing them and sometimes abandoning them, before starting new theoretical sequences (for example, Boltanski and the notion of 'critic'). Thus, whilst 'culture' may be defined as the lowest common denominator of the sub-discipline, it has also regularly been reified and identified with small circles of collaboration, and associated with concepts as well as symbols distinguishing groups from one another.

One paradox reflects this ambivalence: individuals generally describe their own trajectory as 'singular', 'special' or 'particular', while allocating their counterparts to homogeneous groups following linear paths. Similarly, 'commentaries' (Foucault, 1972), including talks, dissertations, reviews, books and articles, are often referenced using reductive identities and labels ('it is a doctoral student of x' or 'he quotes x', 'he must therefore be a X-ian'), even though young researchers often feel that they have made a sufficient theoretical and empirical effort to distinguish themselves from their mentor, $\mathrm{PhD}$ supervisor or associated 'school'. Thus a former doctoral student identi- fied as 'Mengerian' by their referees during their thesis defence defines their work as a refutation of the model proposed by Menger. This way of designating 'culture' through specific concepts and theories, and to some extent circles of collaboration, which publicly mark an individual's affiliation with a group, thus turns it into as many 'emblems' (Pastoureau, 1989).

In this respect it is worth highlighting that theoretical labelling varies according to spaces of enunciation. The key opposition here is between the relatively controlled state- ments of the public scenes of academia (publications, $\mathrm{PhD}$ defences, colloquia, seminars, workshops), and the backstage colloquial speech, anecdotes, spontaneous evaluations, opinions, value judgements, irony, mockery and derision (in coffee places, canteens, offices, libraries, and at parties). As Goffman points out, the social frame on which representations are woven is unveiled backstage (Goffman, 1971). 'Hidden' political, ethical or aesthetic issues, often neglected or ignored in the analysis of theoretical changes (Kuhn, 1962) and ritual (Collins, 1998), are revealed openly through informal associations between people, things (Latour and Woolgar, 1986) and values. Normative aspects, relating to the political scope of a research, the quality of human relationships within the group or style (the way of writing, speaking, dressing, or even considerations of physical and private life), structure evaluations and qualifications. For instance, a researcher labelled as 'Bourdieusian' refers to Le Savant and le populaire in the following terms: 
It's really an important book ... But I feel like Passeron has an annoying way in it of putting himself in the limelight, compared to Grignon. I was really fed up ... Same thing, for a number of his arguments against Bourdieu.

(Interview, with a (junior) sociologist who identifies as a 'Bourdieusian', 2013)

From this perspective, fractal analysis has a twofold interest. On the one hand, it enables us to escape from pure but invisible scientific normativity - researchers being con- stantly both judge and jury. On the other hand, it could initiate a research program reintroducing cultural dimensions in the analysis of research activities through micro dynamics and relational properties. This would invert the position normally held by 'culture' in research activities: it becomes an analytical spectrum rather than an object, a concept or an emblem.

\section{Conclusion}

From a broad perspective, the French sociology of culture could be described as a complex system of concepts and collaborations based on the same matrix. Its members, however, present themselves as part of a divided and conflicted 'turf', claimed by (at least) eight different 'schools'. Despite the 'family air' between them, these sociologists are eager to highlight undisputable distinctions and intangible boundaries. Even though this symbolic and discursive process of formal and informal differentiation may seem secondary with regard to scientific production, it is a major and fundamental part of academic activity. This hiatus suggests that the two-pronged approach touched upon in this article - associating modes of qualification and contexts of production, including apparently trivial dimensions of ordinary criticism and backstage activity - could usefully be developed more systematically. The scholastic tradition once overlooked behind-the- scenes practices, stakes and occupations, even when they played a central role in academic life. Although this remark is generally valid, it also has particular applications regarding the French sociology of culture. Indeed, the analysis of social activity through symbolizations and their social outcomes has been defined as typically French (Lamont, 1992). Regardless of its epistemological status as an object, fetish or variable, 'culture' in France is a central operator of social relations, putting the discussions, introspections, rivalries and conflicts of a small (mostly Parisian) 'turf', and their resolution through symbolic activity, at the centre of public space.

\section{Acknowledgements}

I want to thank Isabelle Darmon and the two reviewers who provided great support and insight, and all my colleagues with whom I've had discussions through my career path although they may not agree with all of the conclusions of this article. 


\section{Funding}

The author(s) received no financial support for the research, authorship, and/or publication of this article.

\section{References}

Abbott A (1988) The System of Professions: An Essay on the Division of Expert Labor. Chicago, IL: Chicago University Press.

Abbott A (1999) Department and Discipline: Chicago Sociology at One Hundred. Chicago, IL: University of Chicago Press.

Abbott A (2001) Chaos of Disciplines. Chicago, IL: University of Chicago Press.

Abbott A and Ollion E (2016) French connections: The reception of French sociology in the USA (1970-2014). European Journal of Sociology 57(2): 331-372.

Alexander JC and Smith P (1998) Sociologie culturelle ou sociologie de la culture ? Un programme fort pour donner à la sociologie son second souffle. Sociologie et sociétés 30(1): 107-116.

Alexandre O (2015) Upside down: Trajectoire croisée en sociologie de l'art et de la culture. In: Paradeise C, Lorrain D and Demazière D (eds) Les sociologies françaises: Héritages et perspectives (1960-2010). Rennes: Presses universitaires de Rennes, pp. 531-544.

Alexandre O (2018) La Sainte Famille des Cahiers du Cinéma: La critique contre elle-même. Paris: Vrin.

Barthes R (2006) The Language of Fashion. Sydney: Powerhouse Publications.

Becker H (1982) Art Worlds. Berkeley: University of California Press.

Becker H (1986) Writing for Social Scientists. Chicago, IL: University of Chicago Press.

Becker H and Faulkner R (2009) Do You Know ...? The Jazz Repertoire in Action. Chicago, IL: University of Chicago Press.

Béra M and Lamy Y (2003) Sociologie de la culture. Paris: Armand Colin.

Bloor D (1991) Knowledge and Social Imagery. Chicago, IL: University of Chicago Press.

Boltanski L and Chiapello E (2005 [1999]) The New Spirit of Capitalism. London: Verso.

Boltanski L and Thévenot L (2006 [1991]) On Justification: Economies of Worth. Princeton, NJ: Princeton University Press. 
Bourdieu P (1984 [1979]) Distinction: A Social Critique of the Judgment of Taste. Cambridge, MA: Harvard University Press.

Bourdieu P (1990 [1984]) Homo Academicus. New York: Polity Press.

Bourdieu P (1996) The Rules of Art: Genesis and Structure of the Literary Field. Stanford, CA: Stanford University Press.

Bourdieu P (1999) The Weight of the World: Social Suffering in Contemporary Society. Cambridge: Polity Press.

Bourdieu P and Passeron JC (1963) Sociologues des mythologies et mythologies des sociologues. Les Temps Modernes 211: 998-1021.

Cervulle M (2013) Dans le blanc des yeux: Diversité, racisme et médias. Paris: Amsterdam.

Collins R (1998) The Sociology of Philosophies: A Global Theory of Intellectual Change. Cambridge, MA: Harvard University Press.

Coulangeon P (2005) Sociologie des pratiques culturelles. Paris: La Découverte.

Détrez C (2014) Sociologie de la culture. Paris: Armand Colin.

Djakouane A (2011) La carrière du spectateur. Temporalités 14. Available at: https://journals.openedition.org/temporalites/1939 (accessed 2 August 2018).

Donnat O (2009) Les pratiques culturelles des français. Paris: La Découverte/Ministère de la Culture et de la Communication.

Dorin S (2013) Dissonance et consonance dans l'amour de la musique contemporaine. Les limites de l'omnivorisme musical dans l'auditoire de l'Ensemble intercontemporain, in Philippe Coulangeon et Julien Duval (dir.), Trente ans après la Distinction de Pierre Bourdieu. Paris : La Découverte, pp. 99-112.

Dubois V (2012) La politique culturelle. Genèse d'une catégorie d'intervention publique. Paris: Belin.

Dubois V (2016) Sociologie de la culture. Encyclopedia Universalis. Available at: www.universalis.fr/encyclopedie (accessed 20 June 2018).

Durand G (1960) Les structures anthropologiques de l'imaginaire. Paris: PUF.

Durkheim E (1912) The Elementary Forms of Religious Life. Oxford: Oxford University Press.

Ethis E (ed.) (2001) Aux marches du palais, le festival de Cannes sous le regard des sciences sociales. Paris: La Documentation française. 
Ethis E (ed.) (2002) Avignon, le public réinventé: Le festival sous le regard des sciences sociales. Paris: La Documentation française.

Esquenazi JP (2004) Godard et la société française des années 60. Paris: Armand Colin.

Esquenazi JP (2010) Les Séries Télévisées. L’avenir du cinéma? Paris: Armand Colin.

Fabiani JL (2016) Pierre Bourdieu: Un structuralisme hérö̈que. Paris: Seuil.

Farrell MP (2001) Collaborative Circles: Friendship Dynamics and Collaborative Work. Chicago, IL: University of Chicago Press.

Fleury L (2014) Sociology of Culture and Cultural Practices: The Transformative Power of Institutions. Lanham, MD: Lexington Books.

Foucault M (1972) The discourse on language. In: Foucault M The Archaeology of Knowledge. New York: Pantheon, pp. 215-237.

Friedberg E and Urfalino P (1984) Le jeu du catalogue: Les contraintes de l'action culturelle dans les villes. Paris: La Documentation française.

Gilmore S (1988) Schools of activity and innovation. Sociological Quarterly 29(2): 203-219.

Godelier M (1986) The Making of Great Men: Male Domination and Power Among the New Guinea Baruya. Cambridge: Cambridge University Press.

Goffman E (1971) Relations in Public: Microstudies of the Public Order. New York: Basic Books.

Gopnik A (2015) The outside game: How the sociologist Howard Becker studies the conventions of the unconventional. The New Yorker, 12 January.

Grignon C and Passeron JC (1989) Le savant et le populaire: Misérabilisme et populisme en sociologie et en littérature. Paris: Seuil/Gallimard.

Griswold W (2008) Cultures and Societies in a Changing World. Thousand Oaks, CA: Pine Forge Press.

Heinich N (1998) Le triple jeu de l'art contemporain: Sociologie des arts plastiques. Paris: Minuit. Heinich N (2001) La sociologie de l'art. Paris: La Découverte.

Hennion A (1993) La passion musicale: Une sociologie de la médiation. Paris: Métailié.

Hughes EC (1971) The Sociological Eye: Selected Papers. New Brunswick, NJ: Transaction.

Johnson R (1986) What is cultural studies anyway? Social Text 16(winter): 38-80. 
Krause M (2016) Clarification? Yes! Standardization? No. Or: What kind of cooperation for the sociology of culture? American Sociologist 47(4): 454-458.

Kuhn TS (1962) The Structure of Scientific Revolutions. Chicago, IL: University of Chicago Press. Lahire B (2004) Culture des individus: Dissonances culturelles et distinction de soi. Paris: La Découverte.

Lahire B (2006) La condition littéraire: La double vie des écrivains. Paris: La Découverte.

Lahire B (2010) The Plural Actor. Cambridge: Polity Press.

Lamont M (1992) Money, Morals and Manners: The Culture of the French and the American Upper-Middle Class. Chicago, IL: University of Chicago Press.

Lamont M (2009) How Professors Think: Inside the Curious World of Academic Judgment. Cambridge, MA: Harvard University Press.

Latour B and Woolgar S (1986) Laboratory Life: The Construction of Scientific Facts. Princeton, NJ: Princeton University Press.

Leveratto JM (2000) La mesure de l'art: Sociologie de la qualité artistique. Paris: La Dispute.

Lévi-Strauss C (1966) The Savage Mind. Chicago, IL: University of Chicago Press.

Lodge D (1984) Small World: An Academic Romance. London: Harvill Secker.

Lynch M (1997) Scientific Practice and Ordinary Action: Ethnomethodology and Social Studies. Cambridge: Cambridge University Press.

Macé E and Maigret E (2005) Penser les médiacultures. Paris: Armand Colin-INA.

Malinas D (2008) Portraits des festivaliers d'Avignon: Transmettre une fois? Pour toujours? Grenoble: PUG.

Mannheim K (1954) Ideology and Utopia: An Introduction to the Sociology of Knowledge. London: Routledge and Kegan Paul.

Martin L (2013) L'Enjeu culturel: La réflexion internationale sur les politiques culturelles. Paris: La Documentation française.

Masson P (2016) Sociology in France After 1945. London: Palgrave.

Mendras H (1995) Comment devenir sociologue ou les mémoires d'un vieux mandarin. Arles: Actes Sud. 
Menger PM (2014 [2009]) The Economics of Creativity: Art and Achievement Under Uncertainty, Cambridge, MA: Harvard University Press.

Moebius S (2008) Kultur: Einfuihrung in die Kultursoziologie. Bielefeld: Verlag.

Moulin R (1987 [1967]) The French Art Market: A Sociological View. New Brunswick, NJ: Rutgers University Press.

Morin E (1957) Les Stars. Paris: Seuil.

Morin E (1962) L’Esprit du temps. Paris: Grasset.

Morin E (2006) Avant-propos. In: Benkirane R and Ziegler ED Culture \& cultures. Les chantiers de l'ethno. Gollion: Infolio éditions, pp. 2-3.

Moulin R (1994) Sociologie de l'art et musée. Publics et musées 5: 100-105.

Muller P (2013) Les politiques publiques. Paris: Presses universitaires de France.

Paradeise C, Lorrain D and Demazière D (eds) (2015) Les sociologies françaises: Héritages et perspectives (1960-2010). Rennes: Presses universitaires de Rennes.

Pasquier D (1999) La culture des sentiments: L'expérience télévisuelle des adolescents. Paris: Éditions de la Maison des Sciences de l'Homme.

Pasquier D (2005) Cultures lycéennes: La tyrannie de la majorité. Paris: Éditions Autrement.

Passeron JC (2005) Le raisonnement sociologique: Un espace non poppérien de l'argumentation. Paris: Albin Michel.

Passeron JC and Pedler E (1991) Le temps donné aux tableaux. Marseille: IMEREC.

Pastoureau M (1989) Couleurs, images, symboles: Études d'histoire et d'anthropologie. Paris: Le Léopard d'Or.

Pedler E and Zerbib O (2001) Nouvelles technologies à l'épreuve des bibliothèques: Usages de l'internet et des cederoms. Paris: BPI.

Pécqueux A and Roueff O (2009) Écologie sociale de l'oreille: Enquêtes sur l'expérience musicale. Paris: Éditions de l'EHESS.

Péquignot B (1991) La relation amoureuse: Analyse sociologique du roman sentimental moderne. Paris: L'Harmattan.

Péquignot B (2000) Pour une sociologie esthétique. Paris: L’Harmattan. 
Perrenoud M (2007) Les musicos: Enquête sur des musiciens ordinaires. Paris: La Découverte.

Pessin A (2004) Un sociologue en liberté: Lecture de Howard S. Becker. Laval: Presses de l'université.

Peyron D (2013) Culture Geek. Limoges: Fyp Editions.

Piriou O (1999) Pour une sociologie des sociologues: Formation, identité, profession. SaintCloud: ENS éditions.

Quemener N (2014) Le pouvoir de l'humour: Politiques des représentations dans les medias en France. Paris: Armand Colin.

Ravet H (2015) Sociologie des arts. Paris: Armand Colin.

Rojek C and Turner B (2000) Decorative sociology: Towards a critique of the cultural turn. The Sociological Review 48(4): 629-648.

Sauvageot A (2007) Sophie Calle: L’art caméléon. Paris: PUF.

Schnapper D (2013) Travailler et aimer: Mémoires. Paris: Odile Jacob.

Shils E (1972) The Intellectuals and the Powers and Other Essays. Chicago, IL: University of Chicago Press.

Smith C (2016) The conceptual incoherence of 'culture' in American sociology. The American Sociologist 47(4). DOI: 10.1007/s12108-016-9308-y.

Star SL and Griesemer J (1989) Institutional ecology, 'translations', and boundary objects: Amateurs and professionals in Berkeley's museum of vertebrate zoology. Social Studies of Science 19(3): 387-420.

Tasset C (2015) Les travailleurs intellectuels précaires: Genèses et réalités d'une figure critique. $\mathrm{PhD}$ thesis, defended at EHESS under the supervision of Luc Boltanski.

Tenbruck FH (1979) Die aufgaben der kultursoziologie. Kölner Zeitschrift für Soziologie und Sozialpsychologie 31: 399-421.

Vörös F (2015) Troubling complicity: Audience ethnography, male porn viewers and feminist critique. Porn Studies 2(2-3): 137-149. 


\section{Author biography}

Olivier Alexandre received his $\mathrm{PhD}$ in sociology from the EHESS and has previously been a visiting scholar at Northwestern and Stanford universities. He is a research fellow at CNRS/LIP6. He works on cinema, media, culture and technology. He recently published La Règle de l'exception (Éditions de 1'EHESS, 2015) and La Sainte famille des Cahiers du cinéma (Vrin, 2018).

\section{Appendix}

Table A1. PhD in sociology obtained in France between 1998 and 2007

\begin{tabular}{|c|c|c|}
\hline Rang & Subfield & Total \\
\hline 1 & Work & 76 \\
\hline 2 & Political Sociology & 58 \\
\hline 3 & Arts and Culture & 54 \\
\hline 4 & Identity et immigration & 53 \\
\hline 5 & Economic sociology & 53 \\
\hline 6 & Health & 46 \\
\hline 7 & Institutions & 41 \\
\hline 8 & Rural studies & 38 \\
\hline 9 & Urban studies & 37 \\
\hline 10 & Religions & 33 \\
\hline 11 & Theory et epistémology & 27 \\
\hline 12 & Ethnology & 26 \\
\hline 13 & Family & 19 \\
\hline 14 & Social mouvements & 19 \\
\hline 15 & Body & 15 \\
\hline 16 & Sports & 14 \\
\hline 17 & Environnement & 13 \\
\hline 18 & Communication & 13 \\
\hline 19 & Exclusion and poverty & 13 \\
\hline 20 & Domestic life & 13 \\
\hline 21 & Deviance & 10 \\
\hline 22 & Vie Associative & 8 \\
\hline 23 & Innovation et technics & 7 \\
\hline 24 & Demography & 6 \\
\hline 25 & Networks & 4 \\
\hline 26 & Genders & 4 \\
\hline 27 & Stratification and social mobility & 3 \\
\hline 28 & Different topic & 8 \\
\hline $\mathrm{n}=\mathbf{2 8}$ & $\mathrm{N}=1660$ & 711 \\
\hline
\end{tabular}

Sources : National PhD file 
Table A2. Participants. N Academic status Location (cf. article for Gender and theoretical label)

- $1 \mathrm{PhD}$ student Paris

. $2 \mathrm{PhD}$ student Paris

. 3 Postdoctoral fellow Province

. $4 \mathrm{PhD}$ student Province

. 5 Postdoctoral fellow Province

. 6 Postdoctoral fellow Paris

. 7 Postdoctoral fellow Paris

. 8 Postdoctoral fellow Province

. 9 Independent researcher Paris

- 10 CNRS Researcher Province

. 11 Lecturer Paris

. 12 Assistant professor Paris

. 13 CNRS Researcher Paris

- 14 Assistant professor Province

- 15 Independent Researcher Paris

. 16 Assistant professor Paris

- 17 Assistant professor Province

- 18 Assistant professor Province

- 19 CNRS Researcher Province

. 20 Assistant professor Province

. 21 Professor Province

. 22 Professor Province

. 23 Professor Paris 
. 24 Professor Province

. 25 Professor Paris

. 26 CNRS researcher Paris

. 27 Independent Researcher Paris

. 28 Professor Paris

. 29 Professor Paris

. 30 DR CNRS Paris

. 31 Independent Researcher Paris

. 32 Professor Paris

. 33 Emeritus Professor Paris

. 34 Emeritus Professor Province 